\title{
Suggested Biomarkers for Major Depressive Disorder
}

\author{
Yunus HACIMUSALAR ${ }^{1}$, Ertuğrul EŞEL ${ }^{2}$ (D) \\ 'Department of Psychiatry, Kayseri Training and Research Hospital, Kayseri, Turkey \\ ${ }^{2}$ Department of Psychiatry, Erciyes University Faculty of Medicine, Kayseri, Turkey
}

\section{ABSTRACT}

Currently, the diagnosis of major depressive disorder (MDD) mainly relies on clinical examination and subjective evaluation of depressive symptoms. There is no non-invasive, quantitative test available today for the diagnosis of MDD. In MDD, exploration of biomarkers will be helpful in diagnosing the disorder as well as in choosing a treatment, and predicting the treatment response. In this article, it is aimed to review the findings of suggested biomarkers such as growth factors, cytokines and other inflammatory markers, oxidative stress markers, endocrine markers, energy balance hormones, genetic and epigenetic features, and neuroimaging in MDD and to evaluate how these findings contribute to the pathophysiology of MDD, the prediction of treatment response, severity of the disorder, and identification of subtypes. Among these, the findings related to the brain-derived neurotrophic factor, the hypothalamo-pituitary-adrenal axis, cytokines, and neuroimaging may be strong candidates for being biomarkers MDD, and may provide critical information in understanding biological etiology of depression. Although the findings are not sufficient yet, we think that the results of epigenetic studies will also provide very important contributions to the biomarker research in MDD.

The availability of biomarkers in MDD will be an advancement that will facilitate the diagnosis of the disorder, treatment choices in the early stages, and prediction of the course of the disorder.

Keywords: Depression, biomarkers, brain-derived neurotrophic factor, cytokines, genetics, neuroimaging

Cite this article as: Hacımusalar Y, Eşel E. Suggested Biomarkers for Major Depressive Disorder. Arch Neuropsychiatry 2018;55:280-290. https://doi.org/10.5152/ npa.2017.19482

\section{INTRODUCTION}

Currently, the diagnosis of major depressive disorder (MDD) mainly relies on clinical examination and subjective evaluation of depressive symptoms. At present there is no approved biomarker as part of the diagnostic criteria for any psychiatric disorder (1-3). However, biomarkers can be helpful in the treatment choice and in predicting the course of the disorder during the early stages. In this paper, articles were scanned by using PubMed, National Academic Network and Information Center (ULAKBIM) and Psychiatry Index databases. For this purpose, in addition to MDD keyword, biomarkers, proteomic markers, growth factors, brain-derived neurotrophic factor (BDNF), cytokines, oxidative stress markers, hypothalamo-pituitary-adrenal (HPA) axis, genetic, brain imaging, hippocampus keywords and their English equivalents were scanned and the appropriate articles were used as a reference. The results of monoaminergic system were not sufficient and consistent therefore except BDNF other growth factors and plasma metabolics data were not included.

In the medical literature, a biomarker is defined as "a property that can be objectively measured and considered as an indicator of a normal biological process, a pathological process, or a response of an individual to a therapeutic intervention" (4). Biomarkers are categorized into two groups, i.e., the diagnostic biomarker which is useful in distinguishing the presence or absence of a disorder and the treatment biomarker which is useful in predicting treatment response. It has been reported to be clinically useful that a biomarker should have high sensitivity and specificity (>80\%) in the diagnosis and classification of a disorder (5). Moreover, for a biomarker to be used in everyday clinical practice, it needs to be reproducible, reliable, inexpensive and non-invasive.

Apart from the distinction between diagnostic and treatment biomarkers, biomarkers are also categorized into three groups as trait, state, and endophenotype markers. Trait biomarkers are persistent and show pathologies that exist before the onset of the disorder, during the disorder, and after remission. These can be used for determining which individuals are at risk for the disorder. On the other hand, state biomarkers are transient, related to the clinical condition, present at the onset of and during the disorder, but normalized with remission. Endophenotypic biomarkers are in fact a subgroup of trait biomarkers, based on the association between genes and specific depressive phenotypes; they are persistent, and found to be higher in family members than in the normal population (2).

Despite great effort having been expended for decades, a noninvasive and quantitative test that can be used for the diagnosis and treatment of MDD has not yet been found (Table 1) (3). The reason for this is the existence of many problems related to the investigation of the biological mechanisms underlying MDD. The main obstacles in this area may consist of the lack of a suitable animal model of depression, the inclusion 
Table 1. Biomarkers for Major Depressive Disorder

\begin{tabular}{|c|c|c|c|c|c|}
\hline Biomarkers & \multicolumn{3}{|c|}{ Major Depressive Disorder } & Change after treatment & Conclusion \\
\hline Serum and plasma BDNF & & Decrease ${ }^{16,22,23}$ & & Normalization $\mathbf{1 6 , 2 2 , 2 3 , 2 7 , 2 8}$ & Candidate \\
\hline $\begin{array}{l}\text { Serum IL-1, IL-6, TNF and } \\
\text { peripheral mRNA expressions }\end{array}$ & Increase ${ }^{, 54,55}$ & & & Normalization ${ }^{56,57}$ & Candidate \\
\hline MDA & Increase ${ }^{65,66}$ & & & Normalization ${ }^{65,66}$ & Candidate \\
\hline SOD & Increase in erythrocytes ${ }^{65,66}$ & Decreased in serum ${ }^{67,68}$ & & & Not consistent \\
\hline HPA activity & Increase ${ }^{\mathbf{7 0 , 7 1}}$ & & & Normalization ${ }^{\mathbf{7 8 , 7 9}}$ & Candidate \\
\hline Cortisol response to DEX/CRH & Increase ${ }^{87}$ & & & Normalization & Candidate \\
\hline Leptin & Increase ${ }^{103,104}$ & Decrease ${ }^{101,102}$ & Unchanged 105,106 & & Not consistent \\
\hline Ghrelin & Increase ${ }^{106}$ & Decrease $^{107}$ & & Increase ${ }^{108}$-Decrease ${ }^{106,109}$ & Not consistent \\
\hline $\begin{array}{l}\text { 5-HT transporter mRNA in } \\
\text { blood }\end{array}$ & Increase ${ }^{111}$ & Decrease $^{112}$ & & & Not consistent \\
\hline Hippocampus volume & & Decrease $^{154}$ & & Normalization 155,156 & Candidate \\
\hline
\end{tabular}

BDNF: Brain-derived neurotrophic factor, IL: Interleukin, TNF: Tumor necrosis factor, mRNA: Messenger ribonucleic acid MDA: Malondialdehyde,

SOD: Superoxide dismutase, HPA: Hypothalamo-pituitary-adrenal DEX/CRH: Dexamethasone/corticotropin releasing hormone HT: Hydroxy tryptamine

of a set of biologically and clinically heterogeneous disorders in MDD, the presence of different subtypes and the continual change of this subgrouping, the high incidence of comorbidities of MDD with many other physical or psychiatric disorders, and the lack of specificity and sensitivity rates of a single biomarker.

The wide variety and nonspecificity of the manifestations of depression may lead to the inclusion of biologically heterogeneous subgroups into MDD as an umbrella term. In this sense, many different disorders are diagnosed as being the same disorder, so the search for a single biomarker in a cluster essentially consisting of different disorders becomes meaningless $(6,7)$. Based on this argument, it seems reasonable to suggest the formation of more homogeneous samples (subtyping) sharing the same symptom groups and to investigate the biological changes in these subtypes. In this article, while we go through individual biomarkers, we will discuss the biologic features that are found in depression subtypes and that are promising for the differentiation of these subtypes from each other if indicated.

In addition, there is also an attempt to find treatment markers that may be useful in treatment selection and in estimating treatment response in MDD. Finding the optimal treatment for depressed patients is still done by the trial and error method, which is also quite time consuming. Therefore, as soon as possible, the discovery of biomarkers that are likely to predict the treatment response appears to be an urgent need for the regulation of individualized treatment (8).

Baron and Kenny (1986) suggested that treatment markers should be treated as two types consisting of moderators and mediators (9). Treatment moderators are the factors which show for whom the treatment will be successful and under what conditions, that is, which patient will benefit more from the treatment (10). In general, treatment moderators are variables that are initially present and predict the treatment response. Therefore, a positive moderator indicates that a particular treatment should be selected, and a negative moderator indicates another one. A treatment mediator is often described as a changing factor in response to a specific intervention (10). Ideally, an early change in the mediator with treatment should inform us of the rate of future recovery from the disorder, and the absence of this change should indicate that the treatment response will be inadequate (11).
Growth factors, cytokines and inflammatory markers, oxidative stress markers, endocrine markers, energy balance hormones, genetic findings, epigenetic studies, structural and functional imaging findings will be discussed in order to be used as biomarkers in MDD.

\section{PROTEOMIC MARKERS}

Proteins are the main actors in the cell. The total protein content of a cell is called the proteome. In depression, growth factors, inflammatory proteins, and oxidative stress-related enzymes have been investigated as proteome.

\section{Growth factors}

In some clinical trials, it has been shown that in patients with MDD, some growth factors (BDNF, vascular growth factor, insulin-like growth factor-1) change both gene expression and peripheral levels, while antidepressants have a normalizing effect $(2,12-14)$.

The most investigated growth factor in MDD is BDNF. BDNF regulates neural plasticity, migration, and survival in the central and peripheral nervous system (15). Apart from neurons, it is also released from peripheral cells such as leukocytes, endothelial cells, and platelets and may pass through the blood-brain barrier (16).

There are sufficient data showing that BDNF is important in the stress response and that it exhibits protective effects against the changes due to stress in the brain. BDNF may reverse the structural and synaptic plasticity changes due to stress in the adult brain, and this effect increases cognitive flexibility, thus adapting to the environment $(17,18)$. It has also been shown in animal studies that physical or psychological stress causes a rapid decrease in hippocampal BDNF expression $(19,20)$. Based on animal studies, it has been suggested that chronic stress exposure reduces neurogenesis and resilience by causing a down-regulation in the BDNF transmission pathways (21). Taken together, it is thought that a reduction in the hippocampal BDNF activity might be directly related to the pathophysiology of MDD, a stress-related disease, and this activity has been extensively studied.

Many studies and meta-analyses have shown that serum and plasma BDNF levels are decreased in depressed patients $(16,22,23)$. It is suggested that the reduction in BDNF levels in depression is probably 
due to increased corticosteroids, because activation of the glucocorticoid receptors (GRs) negatively affects the BDNF gene (24). In this regard, there is no difference between bipolar disorder and MDD (16), although serum BDNF levels are reported to be lower in bipolar depression compared to MDD (25). Also, a finding associated with the subtypes of depression is that BDNF levels in geriatric depression are even lower (26).

In studies and meta-analyses, a consistently reported finding is that the reduction in BDNF levels existing in depression is reversed by antidepressant drugs or electroconvulsive therapy $(\mathrm{ECT})(16,22,23,27$, 28). ECT and long-term use of antidepressants increase hippocampal BDNF expression $(29,30)$. It is suggested that the final common pathway for various antidepressant treatments may be their effect on BDNF levels (31). In addition, initial BDNF levels in patients with MDD responding to treatment have been found to be higher (32). A meta-analysis concluded that BDNF levels could be used as a predictor of successful antidepressant therapy (treatment mediator) because serum BDNF levels remained unchanged in patients who did not respond to antidepressant medications but increased in treatment respondents and those who achieved remission (16).

Despite these findings indicating that BDNF levels in MDD may be regarded as a marker of diagnosis and treatment, there are still significant issues that remain unresolved in this regard. Although the main source of central BDNF is the hippocampus, it is suggested that peripheral BDNF measurements are less likely to reflect central activity because almost all peripheral tissues produce this growth factor. It is also not clear whether peripheral BDNF can cross the blood-brain barrier to produce behavioral effects (33). Moreover, the fact that BDNF changes are not specific to depression and found in many other psychiatric disorders suggests that this may be a neurobiological susceptibility factor for any psychiatric disorder (5).

In addition to these problems, the question of whether peripheral BDNF findings are state or susceptibility markers still appears to be unresolved (2). Although some studies have reported that BDNF levels are lower during full remission from depression compared to healthy controls $(34,35)$, a recent meta-analysis has concluded that BDNF is not lower in remission (16). Moreover, the relationship between depression and BDNF becomes even more complicated by the yet unanswered question of whether the reduction in BDNF expression is the cause or the result of depression $(2,34)$.

Thus, it can be said that findings support the idea that BDNF may be a biomarker for depression. In addition, there seems to be increasing functional importance of BDNF in the understanding of the pathophysiology of depression and in treatment.

\section{Cytokines and inflammatory markers}

Interacting with each other, the neuroendocrine and immune systems play an important role in stress response. For this reason, inflammatory markers have been extensively investigated in stress-related disorders and depression. Evidence supports the view that inflammation may play an important role in the pathophysiology of MDD (36). Inflammatory mediators have been found to affect many factors (monoamine and glutamate neurotransmission, GR resistance, and hippocampal neurogenesis) that are thought to be important in the etiopathogenesis of MDD. This suggests that inflammatory markers may be used as a marker for the diagnosis and treatment response of depression (37).

Cytokines are members of the interleukin (IL) family. They are produced by macrophages, natural killer cells, and T lymphocytes. Cytokines are classified as pro-inflammatory or anti-inflammatory. IL-1, IL-6, and tumor necrosis factor $\alpha$ (TNF $\alpha$ ) are known as pro-inflammatory cytokines, and IL-4, IL-10, and IL-13 are known as anti-inflammatory cytokines (38).
As well as being important in brain development, cytokines play a role in the maintenance of normal brain function by supporting neuronal integrity, neurogenesis, and synaptic remodeling (39). They also create behavioral responses by influencing neurotransmitter systems (40). It has been reported that the cytokines released by peripheral immune cells and adipose tissue enter the central nervous system (CNS) through some regions of the blood-brain barrier or by the active reuptake mechanism and thereby affect behaviors. In the brain, they are mainly produced by microglia and some by astrocytes (41).

It is suggested that inflammatory variables may lead to depression by i) affecting neurotransmitters, ii) decreasing serotonin and inducing glutamate toxicity by stimulating indolamine 2,3 dioxygenase (IDO) in glial cells, iii) suppressing neurogenesis by decreasing BDNF activity, or iv) increasing HPA axis activity $(38,41,42)$. Pro-inflammatory cytokines stimulate IDO in glial cells. IDO converts the tryptophan to kynurenine, which is then converted to neurotoxic quinolinic acid in the brain. Quinolinic acid binds to N-methyl D-aspartate (NMDA) receptors. Thus, because of the pro-inflammatory cytokines inducing IDO, depression may develop as a result of the decrease in serotonin levels due to reduced tryptophan on the one hand and glutamatergic neurotoxicity on the other (42). In a meta-analysis, confirmation of low plasma tryptophan levels in MDD supports the importance of IDO in linking cytokines to depression (43).

Both stress and subsequent inflammatory cytokine activation have been reported to adversely affect neurogenesis and neuroplasticity $(44,45)$. It has been reported that IL-1 suppresses hippocampal proliferation (46) and that cytokines such as TNF $\alpha$ and IL-6 exert a direct suppressive effect on hippocampal neurogenesis $(47,48)$.

Furthermore, it is also known that increased levels of cytokines stimulate the HPA axis (80). The effect of cytokines on the HPA axis may be directly through stimulation of the corticotropin releasing hormone (CRH) (50) or through altering the GR expression to induce GR resistance (51).

Of the inflammatory markers, those which most confirm the changes in depression are proinflammatory cytokines (52) such as IL-1, IL-6 and TNF $\alpha$, and $C$ reactive protein (CRP) (53). It has been reported that serum levels of IL-1, IL-6, and TNF $\alpha$ and the messenger ribonucleic acid (mRNA) expressions of these in peripheral cells are increased in patients with $\operatorname{MDD}(52,54,55)$. In several studies, this increase has been reported to return to normal with antidepressants $(56,57)$. A meta-analysis showed that selective serotonin reuptake inhibitors (SSRIs), in particular, reduce IL-6 and TNF $\alpha$ levels (58). ECT has also been shown to reduce plasma TNF $\alpha$ levels (59).

In some studies, elevated levels of IL-1, IL-6, and TNF $\alpha$ prior to treatment have been reported to be associated with non-response to antidepressant treatment $(55,60)$. These findings suggest that increased inflammatory parameters prior to treatment may be used as biomarkers of poor response to treatment $(37,57)$.

There has started to be research into whether or not cytokine levels differ for some subtypes of depression. It has been reported that there is a more evident increase in proinflammatory cytokines in those attempting suicide, in depression with suicidal ideas, and in geriatric depression (42, 61), whereas atypical and melancholic depressions show increased levels of CRP and IL-6 compared to typical depressions (62).

When all the findings are considered, it can be concluded that depression is accompanied by an imbalance between pro- and anti-inflammatory cytokines and that antidepressant treatment improves this imbalance. At the same time, the results in this area also suggest that cytokines can 
be used as a biomarker for the diagnosis and treatment response of depression. However, based on these results, it is not possible to currently suggest that depression is a primary inflammatory disease (37).

\section{Oxidative stress markers}

Oxidative stress means that the balance between anti-oxidant and prooxidant processes in the cell is permanently degraded in favor of prooxidants. The result is overproduction of reactive oxygen species called free radicals. Free radicals cause damage to structures such as proteins, lipids, and DNA in the cell, and thus trigger apoptosis and cell death (63).

It has been suggested that increased oxidative stress and reduced antioxidant defenses exist in MDD, and that specific components of oxidative stress play a role in the pathophysiology of depression $(63,64)$. Therefore, the biomarkers of oxidative stress are currently being investigated in patients with MDD.

Levels of lipid peroxidation products such as malondialdehyde (MDA) have been reported to be generally elevated in depressed patients (65, 66). There are also studies reporting that MDA levels are higher in patients with recurrent depression than in those with a single episode (67). MDA levels have mostly been reported to decrease and return to normal with antidepressant therapy $(65,66)$.

Another parameter investigated as an oxidative stress marker in patients with MDD is superoxide dismutase (SOD) activity. The results of SOD studies are not as consistent as those in MDA studies. In depressed patients, several studies have reported that serum SOD is decreased $(67$, $68)$ or that erythrocyte SOD is increased $(65,66)$.

A meta-analysis of 17 trials evaluating the majority of lipid peroxidation markers in MDD found that these markers were elevated in patients with depression and found an association between the levels of these and the severity of depression (69).

In summary, although changes in the parameters relation to oxidative stress may be seen in MDD, it can be said that the findings are not strong or consistent enough to suggest that they can be used as a biomarker.

\section{ENDOCRINE MARKERS}

The biological field that was the first to be studied in depression and has collected a large amount of data is the field of endocrine changes. The most studied in this respect is the HPA axis.

In depression, the regulation of the HPA axis seems to be changed. It has been reported that depressed patients have a steady increase in cortisol and $\mathrm{CRH}$ release in a certain proportion of patients, and such findings have been suggested to signal increased HPA activity in MDD $(70,71)$. In accordance with this, CRH mRNA expression has been found to be elevated in different brain structures in patients with MDD who committed suicide or in animal models of depression $(72,73)$. In contrast, there are also recent postmortem studies reporting reduced hippocampal $\mathrm{CRH}$ mRNA expression in patients with MDD (74).

In depressed patients, HPA axis findings including abnormal cortisol levels during awakening, abnormalities in the diurnal rhythm of cortisol release, and abnormal cortisol response to pharmacological suppression tests such as the dexamethasone suppression test (DST) or experimental stress have been reported (75-77). HPA axis changes in depression are accepted as mostly state-dependent, that is, they improve with treatment $(78,79)$. It is suggested that the increased activity of the HPA axis in MDD is largely due to the reduced negative feedback of endogenous glucocorticoids (80). This is also partly related to the reduced GR expression in patients with depression (71). It has been suggested that elevated cortisol in some patients with depression develops to compensate for reduced GR expression and function (81). Indeed, postmortem human studies have shown a reduction in GR mRNA expression in the frontal and temporal regions of patients with MDD (82). Preclinical studies have shown that the use of antidepressants upregulates GR expression and function in the brain, thereby increasing the negative feedback of the HPA axis (71).

To demonstrate HPA axis alterations in MDD, the CRH stimulation test, which has been shown to be more sensitive in this regard, is frequently used in studies $(83,84)$. In this test, depressive patients respond to intravenous (IV) $\mathrm{CRH}$ administration with blunted adrenocorticotropic hormone (ACTH) and normal cortisol release. This finding is considered to be indicative of decreased sensitivity of the hypophyseal $\mathrm{CRH}$ receptor secondary to $\mathrm{CRH}$ hypersecretion (85).

After these initial studies investigating the HPA axis in MDD, the combined dexamethasone- $\mathrm{CRH}$ stimulation test (DEX/CRH) was proposed to further increase the sensitivity of HPA axis findings (86). For this test, samples are taken 15 hours after oral administration of dexamethasone (at 23.00), and then repeated samples are taken after IV CRH is applied. In the DEX/CRH test, depressive patients show increased cortisol response (87). Treatment with antidepressants or ECT has been reported to normalize this abnormal response $(88,89)$. It is reported that relapse risk and treatment resistance rates are high in patients with continued abnormalities in this test $(90,91)$.

Another important finding in this regard is that an increase in cortisol is more prominent in melancholic, psychotic, severe, and elderly depressed patients $(7,79)$. In patients with melancholic depression, plasma cortisol and nonsuppression rates in the DST are significantly higher than in other depressive conditions $(7,92)$. The finding that severity of depression and cortisol responses in the DEX/CRH test are positively correlated confirms that this neurobiological change is more related to severe and melancholic depression $(7,93)$.

In some depression subgroups, the inverse of the aforementioned findings related to the HPA axis is interesting, i.e., excessive suppression with dexamethasone and hypocortisolemia. Over-suppression of cortisol has been reported particularly in atypical depressions $(94,95)$ and in depressed patients with stories of early-life trauma exposure (96).

\section{Energy balance hormones}

Increasingly in recent years, studies have been carried out on the levels of hormones such as leptin and ghrelin that regulate the balance of body energy in MDD. Circulating hormones such as leptin and ghrelin transmit information related to the homeostatic levels of peripheral energy to the brain (97). Chronic stress has been reported to reduce serum leptin levels (98). In addition, it has also been shown that the administration of acute leptin in animals can produce an antidepressant effect, which is accompanied by increased hippocampal BDNF expression $(99,100)$. The leptin level results in patients with MDD are not consistent. Serum or plasma leptin levels were found to be decreased $(101,102)$, increased $(103,104)$, or unchanged $(105,106)$.

The data related to ghrelin in depression are also inconsistent. There are studies that found decreased (107) or increased ghrelin levels (106) and others which reported that it increases $(108)$ or decreases $(106,109)$ with antidepressant treatment.

As a result, we can conclude that the findings related to leptin and ghrelin levels are still inadequate to allow them to serve as biomarkers in depressed patients. 


\section{Genetic findings}

It is known that depression is a disorder that develops as a result of the complex interaction between a large number of genetic and environmental factors. Numerous studies are underway to address both gene expression levels and polymorphisms in genes related to substances in protein structure, such as neurotransmitters, hormones, growth factors, and secondary messengers, which are suggested to play a role in the pathophysiology of MDD, as biomarkers.

Postmortem studies have reported a decrease in 5-hydroxy tryptamine (5-HT)1A mRNA levels in the hippocampus and prefrontal cortex of patients with MDD (110). There are also studies reporting that the levels of 5-HT transporter mRNA in peripheral blood circulation increased (111) or decreased (112) in MDD. A meta-analysis combining postmortem and in vivo imaging studies revealed a decrease in $5-\mathrm{HT}$ transporter expression in many brain regions (113). There are other studies reporting increased platelet 5-HT1A receptor expression in patients with MDD (114).

Polymorphisms in genes associated with serotonin transporter, serotonin $2 \mathrm{~A}$ receptor, monoamine oxidase (MAO)A, BDNF, tryptophan hydroxylase, and GRs have been investigated as potential biomarkers in depression (115-117). When the results of these investigations are taken together, we can conclude that gene studies did not find a single common gene variant that significantly increases the MDD risk.

Furthermore, studies investigating the relationship between gene polymorphisms and response to depression treatment are increasing. Pharmacogenetic research assumes that treatment response or tolerability will be affected by inherited factors. Indeed, some observational studies confirm the hereditary basis of antidepressant treatment outcomes. For this purpose, several gene studies have been carried out including the genes of the serotonin transporter, serotonin receptor-2A, catechol o-methyltransferase (COMT), MAO-A, BDNF, cytochrome P450 enzyme, and $A B C B 1(2,117,118)$. However, the results of these studies are not consistent.

For example; In the study of Mrazek et al. (2009), there was no correlation between genetic variations of serotonin transporter and response to citalopram (119). A more recent meta-analysis has concluded that the long allele of the serotonin transporter gene promoter may be a predictor of better antidepressant response in some races (120). In another study, it was found that single gene polymorphisms of the 5-HT2A receptor may be associated with citalopram response (121).

In addition, associations between the Met allele of BDNF gene Val/ Met polymorphism and response to SSRI and between COMT gene polymorphism and response to some antidepressants have been reported $(122,123)$.

In conclusion, we can state that the data revealing the connection between pharmacodynamic candidate genes and treatment response are not sufficient to be beneficial in clinical use $(33,124)$.

\section{Epigenetic studies}

Today, it is believed that the predisposition to depression is caused by the collective influence of genes and the environment, and that the contribution of heredity is about $30-40 \%$, the latter being complemented by the adverse effects of negative life events (8). Thus, as a result of the combination of genetic predisposition and certain environmental and life events, epigenetic irregularities in the CNS transcriptional program lead to the phenotypic manifestation of MDD (125).

The expression of genes can also be altered by epigenetic factors other than genetic variations. Recognizing epigenetic effects has led to the understanding that the long-term effects of environmental factors on behavioral responses occur by altering gene expression. Because these epigenetic modifications alter gene expression without altering the genetic code and regulate long-term neurobiological adaptations with this mechanism, the discovery of such a mechanism has opened up another dimension in depression studies (126). For example, epigenetic modifications due to stressors in early life may increase or decrease the risk of future depression by affecting the expression of certain receptors (e.g., GR in the hippocampus) (117).

Epigenetic factors include changes such as DNA methylation, histone modification, and microRNA (miRNA) dysregulation (127). Stress has been shown to induce epigenetic mechanisms such as histone modification and DNA methylation, which lead to maladaptive behavior (128). The most consistent findings in this area came from studies investigating the relationship among stress, depression, and epigenetic effects on the BDNF gene (129). It has been reported in animals that stressors such as chronic social stress or maternal separation in the postnatal period lead to decreased BDNF levels in different structures of the brain through histone demethylation and DNA methylation in the BDNF gene promoter region $(128,130)$. Sustained use of antidepressants also reverses stress-induced suppression of BDNF expression through epigenetic mechanisms such as histone-3 acetylation and histone-3 lysine-4 methylation (128). In human studies, changes in DNA methylation in the BDNF gene promoter region were also detected in MDD patients (131).

Epigenetic modifications may also alter the susceptibility to depression via the serotonergic system. For example, it has been reported that there is a positive correlation between childhood adverse life events and hypermethylation of the promoter region of the SLC6A4 gene, the serotonin transporter gene (132). Indeed, in a monozygotic twin study, an association between hypermethylation of the SLC6A4 promoter region in leukocytes and increased score of depression has been reported (133). There are also studies that could not find this relationship (134).

It is also known that epigenetic modifications due to prenatal or early life events may predispose to depression, especially by altering the stress response of the HPA axis for a lifetime. By disrupting the programming of the HPA system through epigenetic pathways, such stressful life events lead to a persistent stress sensitivity in neuroendocrine, autonomic, oxidative, and immune responses (135). The evidence shows that different stress types cause multiple epigenetic changes in both the limbic regions and the HPA axis (136). For example, it has been found that the children of mothers who did not show enough maternal behavior exhibited reduced GR17 expression in adulthood through increased methylation of the GR variant GR17 promoter (137).

miRNAs are small RNA molecules that consist of about 22 nucleotides, which regulate the translation of mRNA but do not carry genetic information themselves, i.e., do not encode proteins (138). miRNAs can alter the expression of $30-50 \%$ of genes encoding neuron specific proteins (139). Until now, over 1,500 different miRNA chains have been reported in humans. The level of miRNA expression in the mammalian brain changes constantly according to environmental stimuli. These molecules affect neuronal development and differentiation, synapse formation, and synaptic plasticity by affecting many cellular processes in the brain (140).

There are findings suggesting that stress exerts its effects on the brain through altering miRNA expressions $(141,142)$. For instance, acute restriction stress in animals causes down-regulation of miR-124 and miR$135 \mathrm{a}$ in the amygdala (143). Similarly, it has been reported that conditions such as maternal separation or chronic social stress in animals have led to an increase in the expression of some miRNAs in the medial prefrontal cortex (144) or a decrease in miR-451 levels in the hippocampus (145), 
and that these changes were reversed with fluoxetine treatment given during adolescence (145).

It has been reported that miRNA levels in serum or peripheral blood cells are altered in depressed patients $(146,147)$, and that global miRNA expression in the prefrontal cortex is reduced in patients who committed suicide (148). It has been proposed that the relationship between depression and miRNA alterations may be mediated by GRs, and that the GR expression in the brain is strongly affected by miRNA, and consequently the changes in GR expression due to early life events may be mediated by miRNA dysfunction, which may also predispose to depression $(138,149)$. It has been further proposed that the miRNA effect may also be brought about by disrupting synaptic plasticity via BDNF or altering the expression of serotonin transporter $(138,150)$.

In summary, it can be suggested that long-term epigenetic modifications play an important role in stress-triggered behavioral responses, susceptibility to depression, and antidepressant response. However, for epigenetic findings to be used as biomarkers in MDD, further research in this field is required.

\section{Structural and functional imaging findings}

Structural and functional imaging studies in MDD are increasingly being conducted and are helping to clarify the neurobiological mechanisms underlying the disorder. Structural and functional changes in MDD have been reported especially in the brain structures related to emotion processing and mood regulation (151).

Unlike bipolar disorder, in patients with MDD there is no global brain volume reduction $(208,151)$. In MDD patients, morphological abnormalities have been reported including volume reduction in several brain structures such as the hippocampus, basal ganglia, anterior cingulate cortex (ACC), orbitofrontal cortex (OFC), and dorsolateral prefrontal cortex (DLPC), decreased cortical thickness, decrease in gray matter volume, and deterioration in white matter integrity $(152,153)$. These regional volumetric changes are thought to be part of the wider neural network and pathways present in depression.

Meta-analyses show that the volumes of both the left and right hippocampus decrease (on average, $4 \%$ on the left and $4.5 \%$ on the right) even in the first episode of depression (154). There are also reports that treatment with antidepressants or ECT reverses the decreased hippocampal volume in patients with depression $(155,156)$. It is, therefore, suggested that volume changes in the hippocampus may be a potential diagnostic marker in depression.

Based on the finding that patients with MDD generally exhibit lower hippocampal volumes during depressive episodes compared to those during remission, there are some who suggest that structural changes in the brain are situational features $(5,155)$, but this is still a controversial issue (152). There are also writers who claim that low hippocampus volume is a genetic predisposition. In relation to this, it has been suggested that Met-BDNF allele carriers have smaller hippocampal volume and may consequently be susceptible to depression (157). Gonul et al. (2011) showed a decrease in the left hippocampal volumes of drugfree depressed patients and that this was associated with Val66Met BDNF gene polymorphism (158).

In addition, it is suggested that the decreased volume of the hippocampus found in depressed patients may be regarded as a marker for the treatment. Two separate studies have shown that larger pre-treatment hippocampal volumes can predict better response to 8-week treatment $(159,160)$. In some meta-analyses, it has been shown that decreased volume of the right hippocampus may be a predictor of insufficient response to treatment in depression (161). There are also studies reporting the same for the left hippocampus (162). These findings provide strong evidence that measurements of hippocampal volume before treatment can be used as moderators of treatment. However, a 2-year follow-up study reported that the presence of a larger hippocampus in males is associated with lower relapse rates (163), implying that hippocampal volume may also be considered as a prognostic marker. A more recent meta-analysis confirmed a positive relationship between increased hippocampal volume and the likelihood of treatment response and increased remission (164).

Functional imaging studies in patients with MDD also reveal important findings. Patients with depression exhibit activity changes in areas such as the OFC, DLPC, ventromedial prefrontal cortex (VMPC), insula, amygdala, and ACC, which are particularly associated with cognitive functions such as the regulation of emotions, cognitive control, and reward processing $(165,166)$. In a meta-analysis, frontal region activity changes in depression were found to be more situational, while striatal changes were trait characteristics of susceptibility (167).

Patients with MDD generally show hypoactive responses to emotional stimuli in the frontal regions and hyperactive responses in the limbic regions (153). For example, when looking at frightened or sad face images, depressed patients show an increased activity in the amygdala, ventral striatum, and medial prefrontal cortex and decreased activity in the dorsal prefrontal cortex (168-170). They respond to a favorable emotional stimulus or a reward expectation with decreased ventral striatal activity $(171,172)$. These functional imaging findings seem to indicate the selective attention of depressed patients to negative stimuli rather than positive emotional and reward related stimuli. Increased activity in the amygdala and striatum is normalized by successful treatment with antidepressants or by cognitive-behavioral therapy $(168,170,173)$; that is, it seems to be a situational feature.

In an earlier meta-analysis, frontal hypometabolism before treatment and the reversal of this with treatment were reported to be the best predictor of treatment response to both antidepressants and cognitivebehavioral therapy (174). In addition, the increase in subgenual ACC activity before treatment and the reduction of this activity with different antidepressant treatments, including cognitive therapy, suggest that this finding can also be used as a marker of treatment response (175). It has been demonstrated in recent studies that increased ACC activity before treatment may predict good response to treatment, and it has been suggested that this increased activity may also include the OFC (161).

\section{CONCLUSION}

Biomarkers can help predict the course of the disorder and the choice of treatment. Although studies investigating biomarkers for MDD have been carried out to facilitate the diagnosis and identification of subgroups, no test is as yet available for this purpose (Table 1). MDD is a clinically and biologically heterogenous disease, with different clinical appearance and courses of sub-groups, and problems such as the low sensitivity and specificity of the recommended markers reduces the benefit of biomarkers in this disease.

As a solution to the problem of low sensitivity and specificity of a single biomarker, some authors have recommended the examination of a biomarker panel of several biological factors rather than a single biomarker in the diagnosis of depression and the evaluation of the response to treatment (11). Thus, it has been suggested that a wider and multivariable approach could be more useful, including a combination of neuro-imaging, genetic, epigenetic, proteomic and metabolomic approaches to include the majority of multiple biological abnormalities, 
which contribute to the differences in the clinical appearance and response to treatment of MDD. Therefore, research of multiple factors would enable the diagnosis and treatment of depression to be personalized and would contribute to the better understanding of the neurobiology of depression sub-types.

Within the parameters examined as potential biomarkers of MDD, some have been studied in more detail and it is noticeable that more consistent results have been obtained. Data related to BDNF seems to be extremely consistent, and it has been shown with great consistency that BDNF is reduced in some areas of the brain in patients with depression and this has been corrected with anti-depressant treatment. Despite the problem of specificity, several authors have accepted from these findings that BDNF is related to the pathophysiology of depression. Similarly, there is great consistency in HPA axis findings in depression and a strong relationship has been established with the pathophysiology of the disease. The DEX/CRH test has been found to be related particularly to the severity of depression and subtypes and promising results have been presented in this area. It can also be said that cytokines, of the potential biochemical markers, and imaging findings are strong candidates both in terms of being markers of depression and in providing important information about the biological etiology of MDD. In addition, although studies have only started in recent years and there are not yet sufficient findings, the results of epigenetic studies can be considered to make an important contribution to the subject of MDD markers.

Although research into biomarkers of MDD has been shown to be useful at a level that could reflect clinical use, better understanding of the biological etiology of MDD and re-organization of the sub-groups of the disease on a biological basis would be of great use.

\section{Peer-review: Externally peer-reviewed.}

Author Contributions: Concept - YH, EE; Design - YH, EE; Supervision - YH, EE; Resource - $\mathrm{YH}$; Materials - $\mathrm{YH}$, EE; Data Collection and/ or Processing - $\mathrm{YH}, \mathrm{EE}$; Analysis and/or Interpretation - YH, EE; Literature Search - YH, EE; Writing - YH, EE; Critical Reviews $\mathrm{YH}, \mathrm{EE}$.

Conflict of Interest: No conflict of interest was declared by the authors.

Financial Disclosure: The authors declared that this study has received no financial support.

\section{KAYNAKLAR}

1. Bandelow B, Baldwin D, Abelli M, Bolea-Alamanac B, Bourin $M$, Chamberlain SR, Cinosi E, Davies S, Domschke K, Fineberg N, Grunblatt E, Jarema M, Kim YK, Maron E, Masdrakis V, Mikova O, Nutt D, Pallanti S, Pini S, Strohle A, Thibaut F, Vaghi MM, Won E, Wedekind D, Wichniak A, Woolley J, Zwanzger P, Riederer P. Biological markers for anxiety disorders, OCD and PTSD: A consensus statement. Part II: Neurochemistry, neurophysiology and neurocognition. World J Biol Psychiatry 2017;18:162-214. [CrossRef]

2. Gururajan A, Clarke G, Dinan TG, Cryan JF. Molecular biomarkers of depression. Neurosci Biobehav Rev 2016;64:101-133. [CrossRef]

3. Lakhan SE, Vieira K, Hamlat E. Biomarkers in psychiatry: drawbacks and potential for misuse. Int Arch Med 2010;3:1. [CrossRef]

4. Biomarkers Definitions Working Group. Biomarkers and surrogate endpoints: preferred definitions and conceptual framework. Clin Pharmacol Ther 2001;69:89-95. [CrossRef]

5. Schneider B, Prvulovic D. Novel biomarkers in major depression. Curr Opin Psychiatry 2013;26:47-53. [CrossRef]

6. Harald B, Gordon P. Meta-review of depressive subtyping models. J Affect Disord 2012;139:126-140. [CrossRef]

7. Kunugi $\mathrm{H}$, Hori $\mathrm{H}$, Ogawa $\mathrm{S}$. Biochemical markers subtyping major depressive disorder. Psychiatry Clin Neurosci 2015;69:597-608. [CrossRef]

8. Labermaier C, Masana M, Müller MB. Biomarkers predicting antidepressant treatment response: how can we advance the field? Dis Markers 2013;35:2331. [CrossRef]
9. Baron RM, Kenny DA. The moderator-mediator variable distinction in social psychological research: conceptual, strategic, and statistical considerations. J Pers Soc Psychol 1986;51:1173-1182.

10. Kraemer HC, Wilson GT, Fairburn CG, Agras WS. Mediators and moderators of treatment effects in randomized clinical trials. Arch Gen Psychiatry 2002;59:877-883.

11. Schmidt HD, Shelton RC, Duman RS. Functional biomarkers of depression: diagnosis, treatment, and pathophysiology. Neuropsychopharmacology 2011;36:2375-2394. [CrossRef]

12. Schmidt HD, Duman RS. The role of neurotrophic factors in adult hippocampal neurogenesis, antidepressant treatments and animal models of depressive-like behavior. Behav Pharmacol 2007;18:391-418. [CrossRef]

13. Sharma AN, da Costa e Silva BF, Soares JC, Carvalho AF, Quevedo J. Role of trophic factors GDNF, IGF-1 and VEGF in major depressive disorder: A comprehensive review of human studies. J Affect Disord 2016;197:9-20. [CrossRef]

14. Iga J, Ueno S, Yamauchi K, Numata S, Tayoshi-Shibuya S, Kinouchi S, Nakataki M, Song H, Hokoishi K, Tanabe H, Sano A, Ohmori T. Gene expression and association analysis of vascular endothelial growth factor in major depressive disorder. Prog Neuropsychopharmacol Biol Psychiatry 2007;31:658-663. [CrossRef]

15. Pittenger C, Duman RS. Stress, depression, and neuroplasticity: a convergence of mechanisms. Neuropsychopharmacology 2008;33:88-109. [CrossRef]

16. Polyakova M, Stuke K, Schuemberg K, Mueller K, Schoenknecht P, Schroeter ML. BDNF as a biomarker for successful treatment of mood disorders: a systematic \& quantitative meta-analysis. J Affect Disord 2015;174:432-440. [CrossRef]

17. Daskalakis NP, De Kloet ER, Yehuda R, Malaspina D, Kranz TM. Early Life Stress Effects on Glucocorticoid-BDNF Interplay in the Hippocampus. Front Mol Neurosci 2015;8:68. [CrossRef]

18. Duman RS. Neurobiology of stress, depression, and rapid acting antidepressants: remodeling synaptic connections. Depress Anxiety 2014;31:291-296. [CrossRef]

19. Nibuya M, Takahashi M, Russell DS, Duman RS. Repeated stress increases catalytic TrkB mRNA in rat hippocampus. Neurosci Lett 1999;267:81-84.

20. Rasmusson AM, Shi L, Duman R. Downregulation of BDNF mRNA in the hippocampal dentate gyrus after re-exposure to cues previously associated with footshock. Neuropsychopharmacology 2002;27:133-142. [CrossRef]

21. Taliaz D, Loya A, Gersner R, Haramati S, Chen A, Zangen A. Resilience to chronic stress is mediated by hippocampal brain-derived neurotrophic factor. J Neurosci 2011;31:4475-4483. [CrossRef]

22. Aydemir O, Deveci A, Taneli F. The effect of chronic antidepressant treatment on serum brain-derived neurotrophic factor levels in depressed patients: a preliminary study. Prog Neuropsychopharmacol Biol Psychiatry 2005;29:261-265. [CrossRef]

23. Gervasoni N, Aubry JM, Bondolfi G, Osiek C, Schwald M, Bertschy G, Karege F. Partial normalization of serum brain-derived neurotrophic factor in remitted patients after a major depressive episode. Neuropsychobiology 2005;51:234-238. [CrossRef]

24. Schaaf MJ, De Kloet ER, Vreugdenhil E. Corticosterone effects on BDNF expression in the hippocampus. Implications for memory formation. Stress 2000;3:201-208.

25. Fernandes BS, Gama CS, Kauer-Sant'Anna M, Lobato MI, Belmonte-de-Abreu $P$, Kapczinski F. Serum brain-derived neurotrophic factor in bipolar and unipolar depression: a potential adjunctive tool for differential diagnosis. J Psychiatr Res 2009;43:1200-1204. [CrossRef]

26. Diniz BS, Teixeira AL, Machado-Vieira R, Talib LL, Radanovic M, Gattaz WF, Forlenza OV. Reduced cerebrospinal fluid levels of brain-derived neurotrophic factor is associated with cognitive impairment in late-life major depression. J Gerontol B Psychol Sci Soc Sci 2014;69:845-51. [CrossRef]

27. Bilgen AE, Bozkurt Zincir S, Zincir S, Ozdemir B, Ak M, Aydemir E, Sener I. Effects of electroconvulsive therapy on serum levels of brain-derived neurotrophic factor and nerve growth factor in treatment resistant major depression. Brain Res Bull 2014;104:82-87. [CrossRef]

28. Gonul AS, Akdeniz F, Taneli F, Donat O, Eker C, Vahip S. Effect of treatment on serum brain-derived neurotrophic factor levels in depressed patients. Eur Arch Psychiatry Clin Neurosci 2005;255:381-386. [CrossRef]

29. Newton SS, Collier EF, Hunsberger J, Adams D, Terwilliger R, Selvanayagam $E$, Duman RS. Gene profile of electroconvulsive seizures: induction of neurotrophic and angiogenic factors. J Neurosci 2003;23:10841-10851.

30. Russo-Neustadt A, Ha T, Ramirez R, KesslakJP. Physical activity-antidepressant treatment combination: impact on brain-derived neurotrophic factor and behavior in an animal model. Behav Brain Res 2001;120:87-95. 
31. Molendijk ML, Bus BA, Spinhoven P, Penninx BW, Kenis G, Prickaerts J, Voshaar RC, Elzinga BM. Serum levels of brain-derived neurotrophic factor in major depressive disorder: state-trait issues, clinical features and pharmacological treatment. Mol Psychiatry 2011;16:1088-1095. [CrossRef]

32. Piccinni A, Del Debbio A, Medda P, Bianchi C, Roncaglia I, Veltri A, Zanello S, Massimetti E, Origlia N, Domenici L, Marazziti D, Dell'Osso L. Plasma Brain-Derived Neurotrophic Factor in treatment-resistant depressed patients receiving electroconvulsive therapy. Eur Neuropsychopharmacol 2009;19:349-355. [CrossRef]

33. Breitenstein B, Scheuer S, Holsboer F. Are there meaningful biomarkers of treatment response for depression? Drug Discov Today 2014;19:539-561. [CrossRef]

34. Bus BA, Molendijk ML, Tendolkar I, Penninx BW, Prickaerts J, Elzinga BM, Voshaar RC. Chronic depression is associated with a pronounced decrease in serum brain-derived neurotrophic factor over time. Mol Psychiatry 2015;20:602-608. [CrossRef]

35. Takebayashi N, Maeshima H, Baba H, Nakano Y, Satomura E, Kita Y, Namekawa $\mathrm{Y}$, Nomoto $\mathrm{H}$, Suzuki $\mathrm{T}$, Arai $\mathrm{H}$. Duration of last depressive episode may influence serum BDNF levels in remitted patients with major depression. Depress Anxiety 2012;29:775-779. [CrossRef]

36. Miller AH, Maletic $\mathrm{V}$, Raison CL. Inflammation and its discontents: the role of cytokines in the pathophysiology of major depression. Biol Psychiatry 2009;65:732-741. [CrossRef]

37. Krishnadas R, Cavanagh J. Depression: an inflammatory illness? J Neurol Neurosurg Psychiatry 2012;83:495-502. [CrossRef]

38. Han QQ, Yu J. Inflammation: a mechanism of depression? Neurosci Bull 2014;30:515-523. [CrossRef]

39. Yirmiya R, Goshen I. Immune modulation of learning, memory, neural plasticity and neurogenesis. Brain Behav Immun 2011;25:181-213. [CrossRef]

40. Haroon E, Raison CL, Miller AH. Psychoneuroimmunology meets neuropsychopharmacology: translational implications of the impact of inflammation on behavior. Neuropsychopharmacology 2012;37:137-162. [CrossRef]

41. Felger JC, Lotrich FE. Inflammatory cytokines in depression: neurobiological mechanisms and therapeutic implications. Neuroscience 2013;246:199-229. [CrossRef]

42. Young JJ, Bruno D, Pomara N. A review of the relationship between proinflammatory cytokines and major depressive disorder. J Affect Disord 2014;169:15-20. [CrossRef]

43. Ogawa S, Fujii T, Koga N, Hori H, Teraishi T, Hattori K, Noda T, Higuchi T, Motohashi N, Kunugi $\mathrm{H}$. Plasma L-tryptophan concentration in major depressive disorder: new data and meta-analysis. J Clin Psychiatry 2014;75:e906-e915. [CrossRef]

44. Peng CH, Chiou SH, Chen SJ, Chou YC, Ku HH, Cheng CK, Yen CJ, Tsai TH, Chang $\mathrm{YL}$, Kao CL. Neuroprotection by Imipramine against lipopolysaccharideinduced apoptosis in hippocampus-derived neural stem cells mediated by activation of BDNF and the MAPK pathway. Eur Neuropsychopharmacol 2008;18:128-140. [CrossRef]

45. KooJW, Russo SJ, Ferguson D, Nestler EJ, Duman RS. Nuclear factor-kappaB is a critical mediator of stress-impaired neurogenesis and depressive behavior. Proc Natl Acad Sci U S A 2010;107:2669-2674. [CrossRef]

46. Kaneko N, Kudo K, Mabuchi T, Takemoto K, Fujimaki K, Wati H, Iguchi $H$, Tezuka H, Kanba S. Suppression of cell proliferation by interferonalpha through interleukin-1 production in adult rat dentate gyrus. Neuropsychopharmacology 2006;31:2619-2626. [CrossRef]

47. Iosif RE, Ekdahl CT, Ahlenius H, Pronk CJ, Bonde S, Kokaia Z, Jacobsen SE, Lindvall $O$. Tumor necrosis factor receptor 1 is a negative regulator of progenitor proliferation in adult hippocampal neurogenesis. J Neurosci 2006;26:9703-9712. [CrossRef]

48. Monje ML, Toda H, Palmer TD. Inflammatory blockade restores adult hippocampal neurogenesis. Science 2003;302:1760-1765. [CrossRef]

49. Dunn AJ. Cytokine activation of the HPA axis. Ann NY Acad Sci 2000;917:608617.

50. Besedovsky HO, del Rey A. Immune-neuro-endocrine interactions: facts and hypotheses. Endocr Rev 1996;17:64-102. [CrossRef]

51. Pace TW, Hu F, Miller AH. Cytokine-effects on glucocorticoid receptor function: relevance to glucocorticoid resistance and the pathophysiology and treatment of major depression. Brain Behav Immun 2007;21:9-19. [CrossRef]

52. Dowlati Y, Herrmann N, Swardfager W, Liu H, Sham L, Reim EK, Lanctot KL. A meta-analysis of cytokines in major depression. Biol Psychiatry 2010;67:446457. [CrossRef]

53. Valkanova V, Ebmeier KP, Allan CL. CRP, IL-6 and depression: a systematic review and meta-analysis of longitudinal studies. J Affect Disord 2013;150:736-744. [CrossRef]
54. Kahl KG, Bens S, Ziegler K, Rudolf S, Dibbelt L, Kordon A, Schweiger U. Cortisol, the cortisol-dehydroepiandrosterone ratio, and pro-inflammatory cytokines in patients with current major depressive disorder comorbid with borderline personality disorder. Biol Psychiatry 2006;59:667-671. [CrossRef]

55. Cattaneo A, Gennarelli M, Uher R, Breen G, Farmer A, Aitchison KJ, Craig IW, Anacker C, Zunsztain PA, McGuffin P, Pariante CM. Candidate genes expression profile associated with antidepressants response in the GENDEP study: differentiating between baseline 'predictors' and longitudinal 'targets'. Neuropsychopharmacology 2013;38:377-385. [CrossRef]

56. Tuglu C, Kara SH, Caliyurt O, Vardar E, Abay E. Increased serum tumor necrosis factor-alpha levels and treatment response in major depressive disorder. Psychopharmacology (Berl) 2003;170:429-433. [CrossRef]

57. Strawbridge R, Arnone D, Danese A, Papadopoulos A, Herane Vives A, Cleare AJ. Inflammation and clinical response to treatment in depression: A metaanalysis. Eur Neuropsychopharmacol 2015;25:1532-1543. [CrossRef]

58. Hannestad J, DellaGioia N, Bloch M. The effect of antidepressant medication treatment on serum levels of inflammatory cytokines: a meta-analysis. Neuropsychopharmacology 2011;36:2452-2459. [CrossRef]

59. Hestad KA, Tonseth S, Stoen CD, Ueland T, Aukrust P. Raised plasma levels of tumor necrosis factor alpha in patients with depression: normalization during electroconvulsive therapy. J ECT 2003;19:183-188.

60. O'Brien SM, Scully P, Fitzgerald P, Scott LV, Dinan TG. Plasma cytokine profiles in depressed patients who fail to respond to selective serotonin reuptake inhibitor therapy. J Psychiatr Res 2007;41:326-331. [CrossRef]

61. Janelidze S, Mattei D, Westrin A, Traskman-Bendz L, Brundin L. Cytokine levels in the blood may distinguish suicide attempters from depressed patients. Brain Behav Immun 2011;25:335-339. [CrossRef]

62. Karlovic D, Serretti A, Vrkic N, Martinac M, Marcinko D. Serum concentrations of CRP, IL-6, TNF-alpha and cortisol in major depressive disorder with melancholic or atypical features. Psychiatry Res 2012;198:74-80. [CrossRef]

63. Siwek M, Sowa-Kucma M, Dudek D, Styczen K, Szewczyk B, Kotarska K, Misztakk P, Pilc A, Wolak M, Nowak G. Oxidative stress markers in affective disorders. Pharmacol Rep 2013;65:1558-1571.

64. Black CN, Bot M, Scheffer PG, Cuijpers P, Penninx BW. Is depression associated with increased oxidative stress? A systematic review and metaanalysis. Psychoneuroendocrinology 2015;51:164-175. [CrossRef]

65. Bilici M, Efe H, Köroğlu MA, Uydu HA, Bekaroğlu M, Değer O. Antioxidative enzyme activities and lipid peroxidation in major depression: alterations by antidepressant treatments. J Affect Disord 2001;64:43-51.

66. Kotan VO, Sarandol E, Kirhan E, Ozkaya G, Kirli S. Effects of long-term antidepressant treatment on oxidative status in major depressive disorder: a 24-week follow-up study. Prog Neuropsychopharmacol Biol Psychiatry 2011;35:1284-1290. [CrossRef]

67. Stefanescu C, Ciobica A. The relevance of oxidative stress status in first episode and recurrent depression. J Affect Disord 2012;143:34-38. [CrossRef]

68. Herken H, Gurel A, Selek S, Armutcu F, Ozen ME, Bulut M, Kap O, Yumru $M$, Savas HA, Akyol O. Adenosine deaminase, nitric oxide, superoxide dismutase, and xanthine oxidase in patients with major depression: impact of antidepressant treatment. Arch Med Res 2007;38:247-252. [CrossRef]

69. Mazereeuw G, Herrmann N, Andreazza AC, Khan MM, Lanctot KL. A metaanalysis of lipid peroxidation markers in major depression. Neuropsychiatr Dis Treat 2015;11:2479-2491. [CrossRef]

70. Eşel E. Depresyondaki nöroendokrinolojik bulgular. Klinik Psikiyatri Derg 2002;Ek 4:35-50.

71. Pariante CM, Miller AH. Glucocorticoid receptors in major depression: relevance to pathophysiology and treatment. Biol Psychiatry 2001;49:391-404.

72. Austin MC, Janosky JE, Murphy HA. Increased corticotropin-releasing hormone immunoreactivity in monoamine-containing pontine nuclei of depressed suicide men. Mol Psychiatry 2003;8:324-332. [CrossRef]

73. Zeng J, Kitayama I, Yoshizato H, Zhang K, Okazaki Y. Increased expression of corticotropin-releasing factor receptor mRNA in the locus coeruleus of stress-induced rat model of depression. Life Sci 2003;73:1131-1139.

74. Mamdani F, Rollins B, Morgan L, Myers RM, Barchas JD, Schatzberg AF Watson SJ, Akil H, Potkin SG, Bunney WE, Vawter MP, Sequeira PA. Variable telomere length across post-mortem human brain regions and specific reduction in the hippocampus of major depressive disorder. Transl Psychiatry 2015;5:e636. [CrossRef]

75. Belvederi Murri M, Pariante C, Mondelli V, Masotti M, Atti AR, Mellacqua Z, Antonioli M, Ghio L, Menchetti M, Zanetidou S, Innamorati M, Amore M. HPA axis and aging in depression: systematic review and meta-analysis. Psychoneuroendocrinology 2014;41:46-62. [CrossRef]

76. Dedovic K, Ngiam J. The cortisol awakening response and major depression: examining the evidence. Neuropsychiatr Dis Treat 2015;11:1181-1189. [CrossRef] 
77. Herbert J. Cortisol and depression: three questions for psychiatry. Psychol Med 2013;43:449-469. [CrossRef]

78. Fink M, Taylor MA. Resurrecting melancholia. Acta Psychiatr Scand Suppl 2007;(433):14-20. [CrossRef]

79. Lloyd RB, Nemeroff CB. The role of corticotropin-releasing hormone in the pathophysiology of depression: therapeutic implications. Curr Top Med Chem 2011;11:609-617.

80. Pariante CM. Risk factors for development of depression and psychosis. Glucocorticoid receptors and pituitary implications for treatment with antidepressant and glucocorticoids. Ann N Y Acad Sci 2009;1179:144-152. [CrossRef]

81. Raison $\mathrm{CL}$, Miller $\mathrm{AH}$. When not enough is too much: the role of insufficient glucocorticoid signaling in the pathophysiology of stress-related disorders. Am J Psychiatry 2003;160:1554-1565. [CrossRef]

82. Klok MD, Alt SR, Irurzun Lafitte AJ, Turner JD, Lakke EA, Huitinga I, Muller CP, Zitman FG, de Kloet ER, Derijk RH. Decreased expression of mineralocorticoid receptor mRNA and its splice variants in postmortem brain regions of patients with major depressive disorder. J Psychiatr Res 2011;45:871-878. [CrossRef]

83. Lesch KP, Laux G, Schulte HM, Pfuller H, Beckmann H. Corticotropin and cortisol response to human $\mathrm{CRH}$ as a probe for HPA system integrity in major depressive disorder. Psychiatry Res 1988;24:25-34.

84. Ehnvall A, Sjogren M, Zachrisson OC, Agren H. HPA axis activation determined by the $\mathrm{CRH}$ challenge test in patients with few versus multiple episodes of treatment-refractory depression. Eur Arch Psychiatry Clin Neurosci 2004;254:349-355. [CrossRef]

85. Holsboer F, Von Bardeleben U, Gerken A, Stalla GK, Müller OA. Blunted corticotropin and normal cortisol response to human corticotropinreleasing factor in depression. N Engl J Med 1984;311:1127. [CrossRef]

86. Heuser I, Yassouridis A, Holsboer F. The combined dexamethasone/CRH test: a refined laboratory test for psychiatric disorders. J Psychiatr Res 1994;28:341-356.

87. Kunugi $H$, Urushibara T, Nanko S. Combined DEX/CRH test among Japanese patients with major depression. J Psychiatr Res 2004;38:123-128.

88. Baghai TC, Schule C, Zwanzger P, Minov C, Holme C, Padberg F, Bidlingmaier M, Strasburger CJ, Rupprecht R. Evaluation of a salivary based combined dexamethasone/CRH test in patients with major depression. Psychoneuroendocrinology 2002;27:385-399.

89. Özsoy S, Eşel E. Elektrokonvulsif tedavinin endokrin etkileri. Turkiye Klinikleri J Psychiatry-Special Topics 2014;7:102-106.

90. Aubry JM, Gervasoni N, Osiek C, Perret G, Rossier MF, Bertschy G, Bondolfi $\mathrm{G}$. The $\mathrm{DEX} / \mathrm{CRH}$ neuroendocrine test and the prediction of depressive relapse in remitted depressed outpatients. J Psychiatr Res 2007;41:290-294. [CrossRef]

91. Holsboer-Trachsler E, Hemmeter U, Hatzinger M, Seifritz E, Gerhard U, Hobi V. Sleep deprivation and bright light as potential augmenters of antidepressant drug treatment-neurobiological and psychometric assessment of course. J Psychiatr Res 1994;28:381-399.

92. Gold PW, Chrousos GP. Organization of the stress system and its dysregulation in melancholic and atypical depression: high vs low CRH/NE states. Mol Psychiatry 2002;7:254-275. [CrossRef]

93. Kunzel HE, Binder EB, Nickel T, Ising M, Fuchs B, Majer M, Pfennig A, Ernst G, Kern N, Schmid DA, Uhr M, Holsboer F, Modell S. Pharmacological and nonpharmacological factors influencing hypothalamic-pituitaryadrenocortical axis reactivity in acutely depressed psychiatric in-patients, measured by the Dex-CRH test. Neuropsychopharmacology 2003;28:21692178. [CrossRef]

94. Levitan RD, Vaccarino FJ, Brown GM, Kennedy SH. Low-dose dexamethasone challenge in women with atypical major depression: pilot study. J Psychiatry Neurosci 2002;27:47-51.

95. Jacobson L. Hypothalamic-pituitary-adrenocortical axis: neuropsychiatric aspects. Compr Physiol 2014;4:715-738. [CrossRef]

96. Yehuda R, Halligan SL, Golier JA, Grossman R, Bierer LM. Effects of trauma exposure on the cortisol response to dexamethasone administration in PTSD and major depressive disorder. Psychoneuroendocrinology 2004;29:389404.

97. Lutter M, Nestler EJ. Homeostatic and hedonic signals interact in the regulation of food intake. J Nutr 2009;139:629-632. [CrossRef]

98. Lu XY, Kim CS, Frazer A, Zhang W. Leptin: a potential novel antidepressant. Proc Natl Acad Sci U S A 2006;103:1593-1598. [CrossRef]

99. Liu J, Garza JC, Bronner J, Kim CS, Zhang W, Lu XY. Acute administration of leptin produces anxiolytic-like effects: a comparison with fluoxetine. Psychopharmacology (Berl) 2010;207:535-545. [CrossRef]

100. Yamada N, Katsuura G, Ochi Y, Ebihara K, Kusakabe T, Hosoda K, Nakao
K. Impaired CNS leptin action is implicated in depression associated with obesity. Endocrinology 2011;152:2634-2643. [CrossRef]

101. Kraus T, Haack M, Schuld A, Hinze-Selch D, Pollmacher T. Low leptin levels but normal body mass indices in patients with depression or schizophrenia. Neuroendocrinology 2001;73:243-247. [CrossRef]

102. Jow GM, Yang TT, Chen CL. Leptin and cholesterol levels are low in major depressive disorder, but high in schizophrenia. J Affect Disord 2006;90:2127. [CrossRef]

103. Esel E, Ozsoy S, Tutus A, Sofuoglu S, Kartalci S, Bayram F, Kokbudak Z, Kula M. Effects of antidepressant treatment and of gender on serum leptin levels in patients with major depression. Prog Neuropsychopharmacol Biol Psychiatry 2005;29:565-570. [CrossRef]

104. Cizza G, Nguyen VT, Eskandari F, Duan Z, Wright EC, Reynolds JC, Ahima RS, Blackman MR; POWER Study Group. Low 24-hour adiponectin and high nocturnal leptin concentrations in a case-control study of communitydwelling premenopausal women with major depressive disorder: the Premenopausal, Osteopenia/Osteoporosis, Women, Alendronate, Depression (POWER) study. J Clin Psychiatry 2010;71:1079-1087. [CrossRef]

105. Deuschle M, Blum WF, Englaro P, Schweiger U, Weber B, Pflaum CD, Heuser I. Plasma leptin in depressed patients and healthy controls. Horm Metab Res 1996;28:714-717. [CrossRef]

106. Ozsoy S, Besirli A, Abdulrezzak U, Basturk M. Serum ghrelin and leptin levels in patients with depression and the effects of treatment. Psychiatry Investig 2014;11:167-172. [CrossRef]

107. Barim AO, Aydin S, Colak R, Dag E, Deniz O, Sahin I. Ghrelin, paraoxonase and arylesterase levels in depressive patients before and after citalopram treatment. Clin Biochem 2009;42:1076-1081. [CrossRef]

108. Pinar M, Gulsun M, Tasci I, Erdil A, Bolu E, Acikel C, Doruk A. Maprotiline induced weight gain in depressive disorder: changes in circulating ghrelin and adiponectin levels and insulin sensitivity. Prog Neuropsychopharmacol Biol Psychiatry 2008;32:135-139. [CrossRef]

109. Kurt E, Guler O, Serteser M, Cansel N, Ozbulut O, Altinbas K, Alatas G, Savas $\mathrm{H}$, Gecici $\mathrm{O}$. The effects of electroconvulsive therapy on ghrelin, leptin and cholesterol levels in patients with mood disorders. Neurosci Lett 2007;426:49-53. [CrossRef]

110. Lopez-Figueroa AL, Norton CS, Lopez-Figueroa MO, Armellini-Dodel D, Burke S, Akil H, Lopez JF, Watson SJ. Serotonin 5-HT1A, 5-HT1B, and 5-HT2A receptor mRNA expression in subjects with major depression, bipolar disorder, and schizophrenia. Biol Psychiatry 2004;55:225-233.

111. Iga J, Ueno S, Yamauchi K, Motoki I, Tayoshi S, Ohta K, Song H, Morita K, Rokutan K, Ohmori T. Serotonin transporter mRNA expression in peripheral leukocytes of patients with major depression before and after treatment with paroxetine. Neurosci Lett 2005;389:12-16. [CrossRef]

112. Lima L, Mata S, Urbina M. Allelic isoforms and decrease in serotonin transporter mRNA in lymphocytes of patients with major depression. Neuroimmunomodulation 2005;12:299-306. [CrossRef]

113. Kambeitz JP, Howes OD. The serotonin transporter in depression: Metaanalysis of in vivo and post mortem findings and implications for understanding and treating depression. J Affect Disord 2015;186:358-366. [CrossRef]

114. Zhang ZJ, Wang D, Man SC, Ng R, McAlonan GM, Wong HK, Wong W, Lee J, Tan QR. Platelet 5-HT(1A) receptor correlates with major depressive disorder in drug-free patients. Prog Neuropsychopharmacol Biol Psychiatry 2014;53:74-79. [CrossRef]

115. Lohoff FW. Overview of the genetics of major depressive disorder. Curr Psychiatry Rep 2010;12:539-546. [CrossRef]

116. Redei EE, Mehta NS. The promise of biomarkers in diagnosing major depression in primary care: the present and future. Curr Psychiatry Rep 2015;17:601. [CrossRef]

117. Young J, Silber T, Bruno D, Galatzer-Levy IR, Pomara N, Marmar CR. Is there Progress? An Overview of Selecting Biomarker Candidates for Major Depressive Disorder. Front Psychiatry 2016;7:72. [CrossRef]

118. Uhr M, Tontsch A, Namendorf C, Ripke S, Lucae S, Ising M, Dose T, Ebinger M, Rosenhagen M, Kohli M, Kloiber S, Salyakina D, Bettecken T, Specht M, Putz B, Binder EB, Muller-Myhsok B, Holsboer F. Polymorphisms in the drug transporter gene $A B C B 1$ predict antidepressant treatment response in depression. Neuron 2008;57:203-209. [CrossRef]

119. Mrazek DA, Rush AJ, Biernacka JM, O'Kane DJ, Cunningham JM, Wieben ED Schaid DJ, Drews MS, Courson VL, Snyder KA, Black JL 3rd, Weinshilboum RM. SLC6A4 variation and citalopram response. Am J Med Genet B Neuropsychiatr Genet 2009;150B:341-351. [CrossRef]

120. Porcelli S, Fabbri C, Serretti A. Meta-analysis of serotonin transporter gene promoter polymorphism (5-HTTLPR) association with antidepressant efficacy. Eur Neuropsychopharmacol 2012;22:239-258. [CrossRef] 
121. Peters EJ, Slager SL, Jenkins GD, Reinalda MS, Garriock HA, Shyn SI, Kraft JB, McGrath PJ, Hamilton SP. Resequencing of serotonin-related genes and association of tagging SNPs to citalopram response. Pharmacogenet Genomics 2009;19:1-10. [CrossRef]

122. Licinio J, Dong C, Wong ML. Novel sequence variations in the brain-derived neurotrophic factor gene and association with major depression and antidepressant treatment response. Arch Gen Psychiatry 2009;66:488-497. [CrossRef]

123. Perlis RH, Fijal B, Adams DH, Sutton VK, Trivedi MH, Houston JP. Variation in catechol-O-methyltransferase is associated with duloxetine response in a clinical trial for major depressive disorder. Biol Psychiatry 2009;65:785-791. [CrossRef]

124. Peters EJ, Slager SL, Kraft JB, Jenkins GD, Reinalda MS, McGrath PJ, Hamilton SP. Pharmacokinetic genes do not influence response or tolerance to citalopram in the STAR ${ }^{*}$ D sample. PLoS One 2008;3:e1872. [CrossRef]

125. Sun H, Kennedy PJ, Nestler EJ. Epigenetics of the depressed brain: role of histone acetylation and methylation. Neuropsychopharmacology 2013;38:124-137. [CrossRef]

126. Vialou V, Feng J, Robison AJ, Nestler EJ. Epigenetic mechanisms of depression and antidepressant action. Annu Rev Pharmacol Toxicol 2013;53:59-87. [CrossRef]

127. Dalton VS, Kolshus E, McLoughlin DM. Epigenetics and depression: return of the repressed. J Affect Disord 2014;155:1-12. [CrossRef]

128. Tsankova NM, Berton O, Renthal W, Kumar A, Neve RL, Nestler EJ. Sustained hippocampal chromatin regulation in a mouse model of depression and antidepressant action. Nat Neurosci 2006;9:519-525. [CrossRef]

129. Januar V, Saffery R, Ryan J. Epigenetics and depressive disorders: a review of current progress and future directions. Int J Epidemiol 2015;44:1364-1387. [CrossRef]

130. Roth TL, Lubin FD, Funk AJ, Sweatt JD. Lasting epigenetic influence of earlylife adversity on the BDNF gene. Biol Psychiatry 2009;65:760-769. [CrossRef]

131. Fuchikami M, Morinobu S, Segawa M, Okamoto Y, Yamawaki S, Ozaki N, Inoue T, Kusumi I, Koyama T, Tsuchiyama K, Terao T. DNA methylation profiles of the brain-derived neurotrophic factor (BDNF) gene as a potent diagnostic biomarker in major depression. PLoS One 2011;6:e23881. [CrossRef]

132. Kang HJ, Kim JM, Stewart R, Kim SY, Bae KY, Kim SW, Shin IS, Shin MG, Yoon JS. Association of SLC6A4 methylation with early adversity, characteristics and outcomes in depression. Prog Neuropsychopharmacol Biol Psychiatry 2013;44:23-28. [CrossRef]

133. Zhao J, Goldberg J, Bremner JD, Vaccarino V. Association between promoter methylation of serotonin transporter gene and depressive symptoms: a monozygotic twin study. Psychosom Med 2013;75:523-529. [CrossRef]

134. Okada S, Morinobu S, Fuchikami M, Segawa M, Yokomaku K, Kataoka T, Okamoto Y, Yamawaki S, Inoue T, Kusumi I, Koyama T, Tsuchiyama K, Terao T, Kokubo Y, Mimura M. The potential of SLC6A4 gene methylation analysis for the diagnosis and treatment of major depression. J Psychiatr Res 2014;53:4753. [CrossRef]

135. Lai MC, Huang LT. Effects of early life stress on neuroendocrine and neurobehavior: mechanisms and implications. Pediatr Neonatol 2011;52:122-129. [CrossRef]

136. Stankiewicz AM, Swiergiel AH, Lisowski P. Epigenetics of stress adaptations in the brain. Brain Res Bull 2013;98:76-92. [CrossRef]

137. Weaver IC, Cervoni N, Champagne FA, D'Alessio AC, Sharma S, Seckl JR, Dymov S, Szyf M, Meaney MJ. Epigenetic programming by maternal behavior. Nat Neurosci 2004;7:847-854. [CrossRef]

138. Dwivedi Y. Emerging role of microRNAs in major depressive disorder: diagnosis and therapeutic implications. Dialogues Clin Neurosci 2014;16:43-61.

139. Hata A, Davis BN. Control of microRNA biogenesis by TGFbeta signaling pathway-A novel role of Smads in the nucleus. Cytokine Growth Factor Rev 2009;20:517-521. [CrossRef]

140. He L, Hannon GJ. MicroRNAs: small RNAs with a big role in gene regulation. Nat Rev Genet 2004;5:522-531. [CrossRef]

141. Leung AK, Sharp PA. MicroRNA functions in stress responses. Mol Cell 2010;40:205-215. [CrossRef]

142. Mendell JT, Olson EN. MicroRNAs in stress signaling and human disease. Cell 2012;148:1172-1187. [CrossRef]

143. Mannironi C, Camon J, De Vito F, Biundo A, De Stefano ME, Persiconi I, Bozzoni I, Fragapane P, Mele A, Presutti C. Acute stress alters amygdala microRNA miR-135a and miR-124 expression: inferences for corticosteroid dependent stress response. PLoS One 2013;8:e73385. [CrossRef]

144. Uchida S, Hara K, Kobayashi A, Funato H, Hobara T, Otsuki K, Yamagata H, McEwen BS, Watanabe Y. Early life stress enhances behavioral vulnerability to stress through the activation of REST4-mediated gene transcription in the medial prefrontal cortex of rodents. J Neurosci 2010;30:15007-15018. [CrossRef]
145. O'Connor RM, Grenham S, Dinan TG, Cryan JF. microRNAs as novel antidepressant targets: converging effects of ketamine and electroconvulsive shock therapy in the rat hippocampus. Int J Neuropsychopharmacol 2013;16:1885-1892. [CrossRef]

146. Mouillet-Richard S, Baudry A, Launay JM, Kellermann O. MicroRNAs and depression. Neurobiol Dis 2012;46:272-278. [CrossRef]

147. Belzeaux R, Bergon A, Jeanjean V, Loriod B, Formisano-Treziny C, Verrier L, Loundou A, Baumstarck-Barrau K, Boyer L, Gall V, GabertJ, Nguyen C, Azorin JM, Naudin J, Ibrahim EC. Responder and nonresponder patients exhibit different peripheral transcriptional signatures during major depressive episode. Transl Psychiatry 2012;2:e185. [CrossRef]

148. Smalheiser NR, Lugli G, Rizavi HS, Torvik VI, Turecki G, Dwivedi Y. MicroRNA expression is down-regulated and reorganized in prefrontal cortex of depressed suicide subjects. PLoS One 2012;7:e33201. [CrossRef]

149. Vreugdenhil E, Verissimo CS, Mariman R, Kamphorst JT, Barbosa JS Zweers T, Champagne DL, Schouten T, Meijer OC, de Kloet ER, Fitzsimons CP. MicroRNA 18 and 124a down-regulate the glucocorticoid receptor: implications for glucocorticoid responsiveness in the brain. Endocrinology 2009;150:2220-2228. [CrossRef]

150. Baudry A, Mouillet-Richard S, Schneider B, Launay JM, Kellermann O. miR16 targets the serotonin transporter: a new facet for adaptive responses to antidepressants. Science 2010;329:1537-1541. [CrossRef]

151. Wise T, Cleare AJ, Herane A, Young AH, Arnone D. Diagnostic and therapeutic utility of neuroimaging in depression: an overview. Neuropsychiatr Dis Treat 2014;10:1509-1522. [CrossRef]

152. Dunlop BW, Mayberg HS. Neuroimaging-based biomarkers for treatment selection in major depressive disorder. Dialogues Clin Neurosci 2014;16:479490.

153. Lener MS, Iosifescu DV. In pursuit of neuroimaging biomarkers to guide treatment selection in major depressive disorder: a review of the literature. Ann N Y Acad Sci 2015;1344:50-65. [CrossRef]

154. Cole J, Costafreda SG, McGuffin P, Fu CH. Hippocampal atrophy in first episode depression: a meta-analysis of magnetic resonance imaging studies. J Affect Disord 2011;134:483-487. [CrossRef]

155. Arnone D, McKie S, Elliott R, Juhasz G, Thomas EJ, Downey D, Williams S Deakin JF, Anderson IM. State-dependent changes in hippocampal grey matter in depression. Mol Psychiatry 2013;18:1265-1272. [CrossRef]

156. Tendolkar I, van Beek M, van Oostrom I, Mulder M, Janzing J, Voshaar RO, van Eijndhoven P. Electroconvulsive therapy increases hippocampal and amygdala volume in therapy refractory depression: a longitudinal pilot study. Psychiatry Res 2013;214:197-203. [CrossRef]

157. Frodl T, Schule C, Schmitt G, Born C, Baghai T, Zill P, Bottlender R, Rupprecht $\mathrm{R}$, Bondy B, Reiser M, Moller HJ, Meisenzahl EM. Association of the brainderived neurotrophic factor Val66Met polymorphism with reduced hippocampal volumes in major depression. Arch Gen Psychiatr 2007;64:410 416. [CrossRef]

158. Gonul AS, Kitis O, Eker MC, Eker OD, Ozan E, Coburn K. Association of the brain-derived neurotrophic factor Val66Met polymorphism with hippocampus volumes in drug-free depressed patients. World J Biol Psychiatry 2011;12:110-108. [CrossRef]

159. MacQueen GM, Yucel K, Taylor VH, Macdonald K, Joffe R. Posterior hippocampal volumes are associated with remission rates in patients with major depressive disorder. Biol Psychiatry 2008;64:880-883. [CrossRef]

160. Vakili K, Pillay SS, Lafer B, Fava M, Renshaw PF, Bonello-Cintron CM, YurgelunTodd DA. Hippocampal volume in primary unipolar major depression: a magnetic resonance imaging study. Biol Psychiatry 2000;47:1087-1090.

161. Fu CH, Steiner H, Costafreda SG. Predictive neural biomarkers of clinical response in depression: a meta-analysis of functional and structural neuroimaging studies of pharmacological and psychological therapies. Neurobiol Dis 2013;52:75-83. [CrossRef]

162. Samann PG, Hohn D, Chechko N, Kloiber S, Lucae S, Ising M, Holsboer $\mathrm{F}$, Czisch M. Prediction of antidepressant treatment response from gray matter volume across diagnostic categories. Eur Neuropsychopharmacol 2013;23:1503-1515. [CrossRef]

163. Kronmüller KT, Pantel J, Köhler S, Victor D, Giesel F, Magnotta VA, Mundt C Essig M, Schröder J. Hippocampal volume and 2-year outcome in depression. Br J Psychiatry 2008;192:472-473. [CrossRef]

164. Chi KF, Korgaonkar M, Grieve SM. Imaging predictors of remission to anti-depressant medications in major depressive disorder. J Affect Disord 2015;186:134-144. [CrossRef]

165. Phillips ML, Chase HW, Sheline YI, Etkin A, Almeida JR, Deckersbach T, Trivedi $\mathrm{MH}$. Identifying predictors, moderators, and mediators of antidepressant response in major depressive disorder: neuroimaging approaches. Am J Psychiatry 2015;172:124-138. [CrossRef] 
166. Eşel E, Kula M, Turan MT, Reyhancan M, Tutuş A, Gönül AS, Baştürk M. Unipolar ve bipolar depresyonlu hastalarda bölgesel beyin kan akımındaki değişiklikler: bir Tc 99M-HMPAO çalışması. Psikiyatri Psikoloji Psikofarmakoloji (3P) Dergisi 2001;9:369-376.

167. Graham J, Salimi-Khorshidi G, Hagan C, Walsh N, Goodyer I, Lennox B, Suckling J. Meta-analytic evidence for neuroimaging models of depression: state or trait? J Affect Disord 2013;151:423-431. [CrossRef]

168. Arnone D, McKie S, Elliott R, Thomas EJ, Downey D, Juhasz G, Williams SR, Deakin JF, Anderson IM. Increased amygdala responses to sad but not fearful faces in major depression: relation to mood state and pharmacological treatment. Am J Psychiatry 2012;169:841-850. [CrossRef]

169. Fales CL, Barch DM, Rundle MM, Mintun MA, Snyder AZ, Cohen JD, Mathews J, Sheline YI. Altered emotional interference processing in affective and cognitive-control brain circuitry in major depression. Biol Psychiatry 2008;63:377-384. [CrossRef]

170. Ruhe HG, Booij J, Veltman DJ, Michel MC, Schene AH. Successful pharmacologic treatment of major depressive disorder attenuates amygdala activation to negative facial expressions: a functional magnetic resonance imaging study. J Clin Psychiatry 2012;73:451-459. [CrossRef]
171. Epstein J, Pan H, Kocsis JH, Yang Y, Butler T, Chusid J, Hochberg H, Murrough J, Strohmayer E, Stern E, Silbersweig DA. Lack of ventral striatal response to positive stimuli in depressed versus normal subjects. Am J Psychiatry 2006;163:1784-1790. [CrossRef]

172. Robinson OJ, Cools R, Carlisi CO, Sahakian BJ, Drevets WC. Ventral striatum response during reward and punishment reversal learning in unmedicated major depressive disorder. Am J Psychiatry 2012;169:152-159. [CrossRef]

173. Fu CH, Williams SC, Cleare AJ, Scott J, Mitterschiffthaler MT, Walsh ND, Donaldson C, Suckling J, Andrew C, Steiner H, Murray RM. Neural responses to sad facial expressions in major depression following cognitive behavioral therapy. Biol Psychiatry 2008;64:505-512. [CrossRef]

174. Mayberg HS. Modulating limbic-cortical circuits in depression: targets of antidepressant treatments. Semin Clin Neuropsychiatry 2002;7:255-268.

175. Siegle GJ, Thompson WK, Collier A, Berman SR, Feldmiller J, Thase $\mathrm{ME}$, Friedman ES. Toward clinically useful neuroimaging in depression treatment:prognostic utility of subgenual cingulate activity for determining depression outcome in cognitive therapy across studies, scanners, and patient characteristics. Arch Gen Psychiatry 2012; 69:913-924. [CrossRef] 